\title{
The mechanism of action of oral anticoagulants and its consequenses for the practice of oral anticoagulation
}

Citation for published version (APA):

Hemker, H. C., \& Frank, H. L. L. (1985). The mechanism of action of oral anticoagulants and its consequenses for the practice of oral anticoagulation. Haemostasis, 15(4), 263-270. https://doi.org/10.1159/000215158

Document status and date:

Published: 01/01/1985

DOI:

10.1159/000215158

Document Version:

Other version

Please check the document version of this publication:

- A submitted manuscript is the version of the article upon submission and before peer-review. There can be important differences between the submitted version and the official published version of record.

People interested in the research are advised to contact the author for the final version of the publication, or visit the DOI to the publisher's website.

- The final author version and the galley proof are versions of the publication after peer review.

- The final published version features the final layout of the paper including the volume, issue and page numbers.

Link to publication

\footnotetext{
General rights rights.

- You may freely distribute the URL identifying the publication in the public portal. please follow below link for the End User Agreement:

www.umlib.nl/taverne-license

Take down policy

If you believe that this document breaches copyright please contact us at:

repository@maastrichtuniversity.nl

providing details and we will investigate your claim.
}

Copyright and moral rights for the publications made accessible in the public portal are retained by the authors and/or other copyright owners and it is a condition of accessing publications that users recognise and abide by the legal requirements associated with these

- Users may download and print one copy of any publication from the public portal for the purpose of private study or research.

- You may not further distribute the material or use it for any profit-making activity or commercial gain

If the publication is distributed under the terms of Article $25 \mathrm{fa}$ of the Dutch Copyright Act, indicated by the "Taverne" license above, 


\title{
The Mechanism of Action of Oral Anticoagulants and Its Consequences for the Practice of Oral Anticoagulation
}

\author{
H.C. Hemker, H.L.L. Frank \\ Departments of Biochemistry and Cardiology, Rijksuniversiteit Limburg, Maastricht, The Netherlands
}

Key Words. Clotting factors · Vitamin K · Oral anticoagulants

Abstract. A short review on the discovery of the relation between vitamin $\mathrm{K}$ and the synthesis of clotting factors and on the development of anticoagulant therapy is given. The procoagulant activity induced by vitamin $\mathrm{K}$ resides in the postribosomal modification of $\mathrm{N}$ terminal glutamic acids in $\gamma$ - $\mathrm{COOH}$ glutamic acids. The mode of action of oral anticoagulants is explained. The concentration-effect relations and the choice of an oral anticoagulant is discussed.

\section{History}

In the 1920s and 1930s, two different lines of research led to the discovery of vitamin $\mathrm{K}$ and its antagonists. Dam and co-workers [1, 2] as well as Almquist and Stokstead [3] observed an acquired bleeding syndrome in chicken which were fed a fat-free diet. Dam et al. [2] postulated the existence of a nutrition factor that was essential for normal hemostasis, and called it vitamin $\mathrm{K}$. By clinical observations on patients suffering from hepatic cirrhosis and obstruction of the biliary ducts and also by animal experiments, it soon became clear that intimate links exist between liver function, gall secretion, vitamin $\mathrm{K}$ and the synthesis of clotting factors.

Only 10 years after the first announcement of the possible existence of vitamin $\mathrm{K}$, its chemical structure and its synthesis were reported [4, 5]. In 1943, Dam and Doisy obtained the Nobel Prize for this work. Another line of research started, when, in 1920, Schofield, [6] a veterinarian from the United States, described a hemorrhagic diathesis in cattle that was caused by the ingestion of spoiled, sweet clover. The cause of the bleeding could be identified as an extremely low 'prothrombin' level [7], which, interpreting the data of that time in terms of the knowledge of today means low levels of the vitamin K-dependent clotting factors. In 1940, Link [8] could define dihydroxycoumarin as the toxic substance responsible for the low level of clotting factors. He could also show that these substances acted as vitamin $\mathrm{K}$ antagonists. Later it was found that two different basic structures could serve as vitamin $\mathrm{K}$ antagonists: $4-\mathrm{OH}$ coumarins and 1,3indanedione [8]. All oral anticoagulants 
presently in use are derivatives of these substances.

Recently the so-called 'superwarfarins' have been developed that are characterized by an extremely slow elimination from the body. These substances are used as rodenticides rather than as oral anticoagulants for humans [9].

Clinical experience in the 1930s showed that antivitamin $\mathrm{K}$ drugs could be useful therapeutics in thromboembolic events [for review, see 10]. Thus, after 1941, they found a place in the therapeutic arsenal, especially for treating venous thrombosis. Their use in the treatment of arterial thrombosis remained a matter of debate during many years and, as a matter of fact, hardly can be considered to be settled at this moment, were it not for the recent work of Loeliger et al. [11]. In fact the continuing debate on this matter may be caused by the fact that for arterial thrombosis the gap between efficient therapeutics and an unacceptable risk of bleeding, i.e. the therapeutic range, is extremely narrow, whereas in venous thrombosis it is somewhat wider (see elsewhere in this volume). It has been Loeliger's merit to devote his efforts to (a) defining the width of the therapeutic range, and (b) finding ways to maintain a large proportion of the patients under treatment within this range.

\section{Procoagulant Activity of Vitamin K}

The first problem that Loeliger asked me (H.C.H.) to tackle when I became the research biochemist in his department in 1962 was a practical problem in the control of oral anticoagulation. A patient with hepatic cirrhosis and a level of the vitamin K-dependent coagulation factors of about $30 \%$ will show a Thrombotest percentage of $30 \%$ as well, which is to be expected because factors II, VII and X determine the Thrombotest value. A patient under anticoagulant treatment however, who also has $30 \%$ of each of the factors II, VII and X, will show only about $15 \%$ in the Thrombotest.

An application of enzyme kinetic techniques to the analysis of clotting tests enabled us to show that in the plasma of these patients a protein occurs that inhibits the Thrombotest but not, or hardly, the determination of clotting factors. This inhibitor could be shown to be a prothrombin-like protein. We therefore drew the conclusion that vitamin $K$ acts as a postribosomal modifier of a precursor protein [12]. The inhibitor itself we called PIVKA - protein induced by vitamin $\mathrm{K}$ absence. It is a pleasure to see that this name by now is widely accepted in the coagulation literature, be it more often than not without a citation.

One year later, Josso et al. [pers. commun.] showed that plasma from anticoagulated patients indeed contained two populations of molecules that both reacted with antiprothrombin antibodies, but that differed in electrophoretic mobility in the presence of $\mathrm{Ca}^{++}$ ions. They did not publish their results until 1968 [14], at the same time as Ganroth and Niléhn [13]. Later we could demonstrate the existence of similar analogues of the other vitamin $\mathrm{K}$-dependent factors, both in man and in the cow [15]. They did not occur in the chicken or the rat though. Also we could show that the inhibition of coagulation by PIVKA takes place at the level of factor $\mathrm{X}$, so that PIVKA-X probably is the inhibitory protein. The inhibition by PIVKA is specific for human plasma, it is not observed in the cow.

It is important for the practice of the control of oral anticoagulation that the inhibition 
by PIVKA is dependent upon the type of thromboplastin used. It is evidently a phospholipid-dependent phenomenon. Nonphysiological prothrombin activators such as Echis carinatus venom, trypsin or staphylocoagulase activate PIVKA like they activate normal prothrombin [16]. These activators can therefore not be used for the control of anticoagulant treatment. The fact that $E$. carinatus venom contains a factor $\mathrm{X}$ activator as well as a factor II-activating enzyme may sometimes cause confusion in this matter [17].

A combination of our kinetic work and the findings of Josso et al. [14] and Ganroth and Niléhn [13] led to the conclusion that the procoagulant activity induced by vitamin $\mathrm{K}$ resides in a postribosomal modification of the vitamin $\mathrm{K}$-dependent coagulation factors that also involved their $\mathrm{Ca}^{++}$binding properties. It was Stenflo [18, 19], who at the Second Boerhaave Conference in Leyden in 1974 revealed what was the nature of the chemical change involved. As he stated: normal prothrombin is an abnormal protein in that the glutamic acid residues at its $\mathrm{N}$-terminal end have been modified to $\gamma-\mathrm{COOH}$ glutamic acids. Abnormal prothrombin, on the contrary, is a normal protein that contains only normal glutamic acids.

\section{Vitamin K-Dependent Carboxylation and the Vitamin K Cycle}

In the hepatocyte, vitamin $\mathrm{K}$ functions in a metabolic cycle coupled to the carboxylation of the glutamyl residues at the $\mathrm{N}$-terminal end of the vitamin K-dependent clotting factors. In many other organs, including kidney, bone, testis and arterial (but not venous!) wall, vitamin K-dependent carboxyla- tion takes place. The nature and function of the proteins thus produced is often unknown and we will restrict ourselves to a discussion of clotting factor synthesis in the liver.

Two questions apparently arise here. First why are some proteins carboxylated and only in specific residues? And second, what is the molecular mechanism of this carboxylation? The first question can as yet not be answered. The carboxylase is situated at the inside of the rough endoplasmatic reticulum. Therefore, only the proteins that are to be secreted by the cell can be carboxylated, but the specificity of this conversion within this group of proteins is as yet an unsolved problem. The second question can be considered to be largely solved however. The finding by $D e$ Metz et al. [20] of vitamin K hydroperoxide as an intermediate in the vitamin $\mathrm{K}$ cycle enabled to arrive at a plausible molecular mechanism of carboxylation. Some details remain to be solved, but the broad lines are as depicted in figure 1 . In the vitamin $\mathrm{K}$ cycle, concurrent with carboxylation, a vita$\min \mathrm{K}$ epoxide is formed that has to be reduced in two steps so as to form vitamin $\mathrm{K}$ hydroperoxide again. In vitro, working with the purified carboxylase, many different agents may serve to bring about these reductions. What the specific reducing agent is in vivo remains as yet unknown. This question may not be unimportant though, because it may be relevant for the design of oral anticoagulant treatment, as we will presently see.

\section{Mode of Action of Oral Anticoagulants}

Oral anticoagulants do not interfere with vitamin $\mathrm{K}$-dependent carboxylation per se, but they block the vitamin $\mathrm{K}$ cycle by blocking its reducing reactions $[21,22] . \gamma-\mathrm{Hy}-$ 


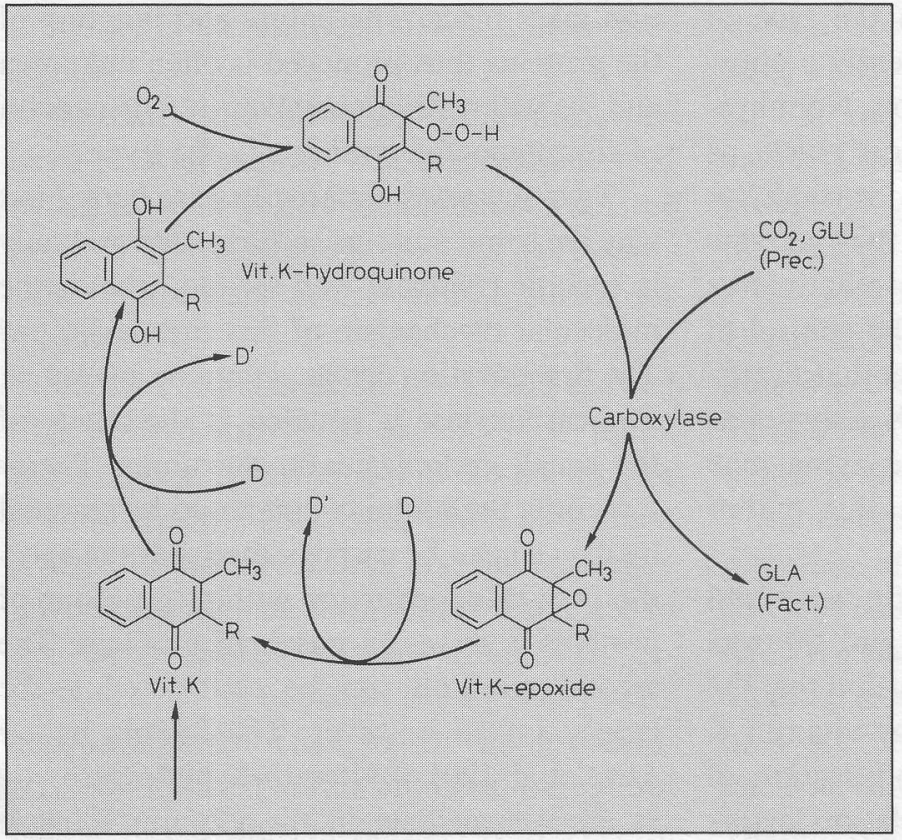

Fig. 1. The vitamin $\mathrm{K}$ cycle. The arrow at the lower left corner indicates the site of entry of exogenous vitamin $\mathrm{K}$. droxycoumarins and indanediones share this type of action. The quinone reductase is more sensitive to the inhibition than the epoxide reductase is, at least in vitro $[23,24]$. It does appear possible however that there is not one unique reductase but one or more specific ones located in the endoplasmatic reticulum that are sensitive to oral anticoagulants and besides that an aspecific $\mathrm{NAD}(\mathrm{P}) \mathrm{H}$-dependent one in the cytosol that only functions at high concentrations of vitamin $\mathrm{K}$.

It has been found that vitamin $\mathrm{K}$, administered orally to anticoagulated patients, occurs in the plasma in its epoxy form. This suggests preferential inhibition of the first reduction step, but it may also be due to the fact that an excess of the quinone can be transformed into the hydroquinone by an aspecific uninhibited pathway. This would not be without interest for anticoagulant therapy. It has been observed in rats [ Vermeer, pers. commun.] that the simultaneous administration of vitamin $\mathrm{K}$ and an anticoagulant in relatively high doses results in a more stable anticoagulation than the administration of the anticoagulant alone. This may be a pharmacokinetic effect but it may also result from complete inhibition of one or both specific reductases and the bypassing of the aspecific reductases by NAD(P)H-dependent reductases in the cytosol.

\section{Concentration-Effect Relations}

The vitamin $\mathrm{K}$-dependent clotting factors (factors II, VII, IX and X, proteins C and S), like all other plasma proteins, obtain a steady-state concentration in the plasma because they are synthesized at a given rate and 
Table I. Data on the synthesis of vitamin Kdependent coagulation factors

\begin{tabular}{llrrrc}
\hline Factor & MW & \multicolumn{1}{c}{ t1/2 } & \multicolumn{1}{l}{ C } & \multicolumn{1}{c}{ K } & SR \\
\hline II & 66,000 & 60 & 1,500 & 1.6 & 77.8 \\
VII & 45,500 & 6 & 10 & 11.6 & 7.25 \\
IX & 70,000 & 14 & 70 & 4.95 & 15.7 \\
X & 55,000 & 40 & 180 & 1.73 & 15.0 \\
\hline
\end{tabular}

MW = molecular weight; $t^{1 / 2}=$ half-life time (h); $\mathrm{C}=$ plasma concentration (nmol); $\mathrm{K}=$ breakdown constant; $\mathrm{SR}=$ synthesis rate, $\mathrm{nmol} / \mathrm{h}$ for a man of about $70 \mathrm{~kg}$.

broken down with a velocity that is proportional to their concentration. When the synthesis is blocked the clotting factors disappear from the plasma in a process that, if we disregard the exchange with extravascular space for the moment, may be described as a monoexponential decay.

The velocity of the decay is determined by the half-life of the clotting factors - factor VII and protein $\mathrm{C}$ disappearing the fastest, prothrombin slowest (table I). If the synthesis is not completely blocked but for example inhibited to $20 \%$ of its original value, then a new equilibrium will be found when again the breakdown velocity is equal to the new velocity of synthesis. Because the breakdown velocity is directly proportional to the plasma level of the clotting factor - as can be concluded from the monoexponential decay - the clotting factor level in the new steadystate equilibrium will be $20 \%$ of the normal level. In general, the level of clotting factors in the equilibrium situation reflects the degree of inhibition of the synthesis system. From the fact that in good approximation all vitamin K-dependent clotting factors de- crease to the same level in steady oral anticoagulation [25], it can therefore be concluded that prothrombin carboxylase is inhibited to the same extent as factor VII carboxylase. It cannot be excluded that the same enzyme serves to carboxylate all coagulation factors.

If it were theoretically possible to inhibit the synthesis in a sudden way to a stable $20 \%$ level, then the factors would approach their new level in a monoexponential way, again determined by their half-life times. That is why the half-life times of the vitamin $\mathrm{K}$ dependent factors are important for the understanding of the management of anticoagulation. In general, it is considered to last 4-5 times the half-life time before a new equilibrium is approached. Factor VII will therefore be at its steady inhibited level in about 1 day, but for factor II this will last more then 10 days. The inhibition of clotting factors synthesis obtained by the daily intake of an oral anticoagulant needs by no means be stable however. It depends upon the antagonism in the liver cell of the anticoagulant and vitamin $\mathrm{K}$. The fluctuations in the concentration of the drug may be important if an anticoagulant is used that is eliminated quickly, such as acenocoumarol. The half-life time of this drug on itself is about $10 \mathrm{~h}$, so that the level of the drug at the site of action will vary from an optimum shortly after oral intake and a minimum just before intake that is only 15$25 \%$ of the optimum. Because the coagulation factors have their own half-life time, the plasma levels will follow these fluctuations with an appreciable backlash (fig. 2, 3). Because of its long half-life time, prothrombin levels will hardly vary, even when a shortlived coumarin derivative is used. Factor VII and protein $\mathrm{C}$ however will show important variations. This has two important conse- 


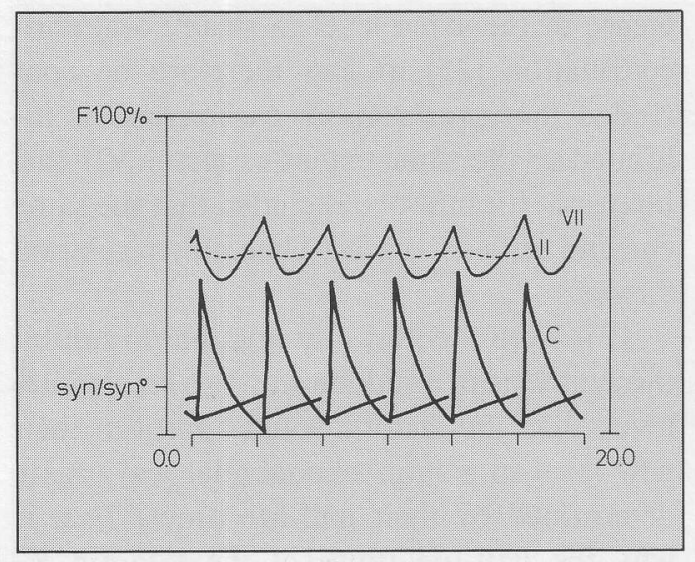

Fig. 2. The effect of a short-lived anticoagulant on the plasma levels of factors II and VII. Computer simulation of the effects of a drug with a half-life time of $10 \mathrm{~h} . \mathrm{C}=$ plasma level of the drug; syn $/ \mathrm{syn}^{\circ}=$ relative rate of synthesis in the liver; II = plasma level of factor II; VII = plasma level of factor VII [26].

quences. In the first place factor VII may, during appreciable parts of the day, be either above the level that ensures adequate anticoagulation or below the level that guarantees safe anticoagulation. Because the importance for the state of anticoagulation of the individual clotting factors remains unknown, we do not now what upper and lower levels of factor VII are compatible with adequate thrombosis prevention. It would therefore be prudent to maintain this factor within the levels that are known to be safe on the bases of overall tests (say 10-20\%). This cannot be achieved with a short-lived drug like acenocoumarol.

The other risk of using a short-lived drug is the fact that the fluctuating levels of factor VII will cause fluctuations in the outcome of the test used to monitor the therapy. When the time lap between drug intake and blood sampling varies this will cause the daily variations that are to be expected if a short-lived

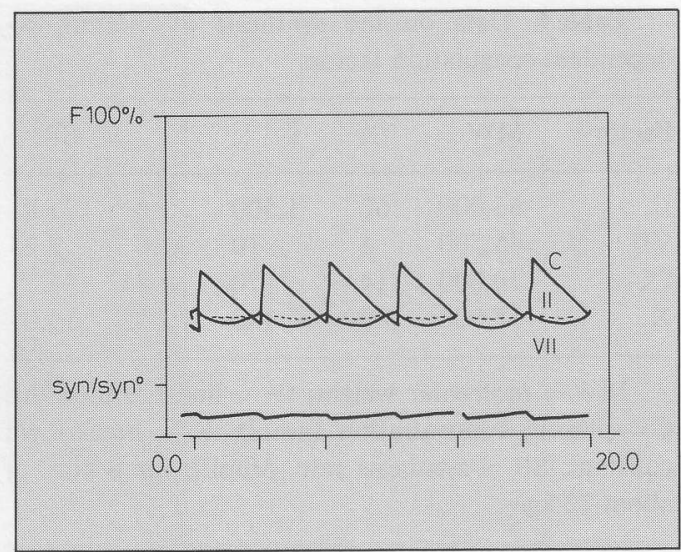

Fig. 3. The effect of a long-lived anticoagulant in the plasma levels of factors II and VII. As figure 2 but for a drug with a half-life time of $70 \mathrm{~h} \mathrm{[26].}$

drug us used, to appear as changes in the level of steady-state anticoagulation. It thus is easily understood that even a very good thrombosis service will maintain only about $75 \%$ of its patients within the proper boundaries of anticoagulation if acenocomarol is used. With a long-lived anticoagulant, such as phenprocoumon (half-life time $\simeq 5$ days), $85-90 \%$ of the patients are within the limits. The effect of this on the success of therapy has not been systematically studied until now but for one case [Lubsen, pers. commun.]. In a study of the Interuniversity Cardiological Institute of The Netherlands on the influence of anticoagulant therapy on the patency of coronary bypasses, it could be shown that the odds ratio, i.e. the ratio of the risk of occlusion in the presence of therapy over that in the absence of therapy, is 0.6 for acenocoumarol treatment and 0.3 for phenprocoumon treatment. These differences are 
significant. It may be noted, moreover, that the odds ratio for antiplatelet treatment is a nonsignificant 0.8 .

\section{Choice of an Oral Anticoagulant}

From the above it will be clear that on the basis of our understanding of the mechanism of action of oral anticoagulant, a long-acting anticoagulant is by far to be preferred. Yet the short-acting acenocoumarol is by far the most used. In several European countries phenprocoumon cannot even be obtained. This is largely due to a misunderstanding of the nature of the 'quick-acting', short-lived anticoagulants.

It is largely thought that acencoumarol will produce the desired level of anticoagulation more quickly than phenprocoumon. The uptake of both drugs and their mode of action are completely comparable however. The onset of an acceptable level of anticoagulation is determined by a physiological constant: the disappearance rate of the clotting factors, and by that constant only.

The other admitted advantage of a shortlived anticoagulant is that cessation of therapy suffices to obtain normal coagulability. This is indeed true. If, however, phenprocoumon therapy is stopped by daily administration of 5-10 $\mathrm{mg}$ vitamin $\mathrm{K}$ for a week then there is no difference whatsoever in the velocity of approach to normal coagulability; again because it is the physiological synthesis rate of the clotting factors rather then the pharmacokinetics of the drug that determines the course of events.

A consideration of the pros and cons of short- and long-lived anticoagulants must therefore inevitably decide in favour of the long-lived ones [26].

\section{References}

1 Dam, H.: Haemorrhages in chicks raised on artificial diets: new deficiency disease. Nature, Lond. 133: 909-910 (1934).

2 Dam, H.; Schønheyder, F.; Tage-Hansen, E.: Studies on the mode of action of vitamin K. Biochem. J. 30: 1075-1079 (1936).

3 Almquist, H.J.; Stokstead, E.L.R.: Hemorrhagic chick disease of dietary origin. J. biol. Chem. 111 . 105-113 (1935).

4 Fieser, L.F.; Campbell, W.P.; Fry, E.M.: Synthesis of quinones related to vitamines $\mathrm{K}_{1}$ and $\mathrm{K}_{2}$. J. Am. chem. Soc. 61: 2206-2218 (1939).

5 Doisy, E.A.; MacCorguodale, D.W.; Thayer, S.A.: The isolation, constitution and synthesis of vitamin $K_{1}$. Science 90: 407 (1939).

6 Schofield, F.W.: Damaged sweet clover: cause of a new disease in cattle simulating hemorrhagic septicemia and blackleg. J. Am. vet. med. Ass. 64: 553575 (1924).

7 Roderick, L.M.: A problem on the coagulation of blood. Sweet clover disease of cattle. Am. J. Physiol. 96: 413-425 (1931).

8 Link, K.P.: Discovery of dicumarol and its sequels. Circulation 19: 97-107 (1959).

9 Lipton, A.R.; Klass, E.M.: Human ingestion of a 'superwarfarin' rodenticide resulting in a prolonged anticoagulant effect. J. Am. med. Ass. 252: 3004-3005 (1984).

10 Renk, E.; Stoll, W.G.: Oral anticoagulation Prog. Drug Res. 11: 228-355 (1968).

11 Vries, W.A. de; Tijssen, J.G.P.; Loeliger, E.A.; Roos, J.: A double-blind trial to assess long-term oral anticoagulant therapy in elderly patients after myocardial infarction. Report of the Sixty Plus Reinfarction Study Research Group. Lancet ii: 989-994 (1980).

12 Hemker, H.C.; Veltkamp, J.J.; Hensen, A.; Loeliger, E.A.: Nature of prothrombin biosynthesis: preprothrombinaemia in vitamin $\mathrm{K}$ deficiency. Nature, Lond. 200: 589-590 (1963).

13 Ganrot, P.O.; Niléhn, J.E.: Plasma protein during treatment with dicoumarol. II. Demonstration of an abnormal prothrombin fraction. Scand. J. clin. Lab. Invest. 22: 23-28 (1968).

14 Josso, F.; Lavergne, J.M.; Gouault, M.; Prou-Wartelle, O.; Soulier, J.P.: Different molecular states of factor II (prothrombin). Tromb. Diath. haemorrh. 20: 88-89 (1968). 
15 Reekers, P.P.M.; Lindhout, M.J.; Kop-Klasen, B.H.M.; Hemker, H.C.: Demonstration of three anomalous proteins induced by a vitamin $\mathrm{K}$ antagonist. Biochem. biophys. Acta 317: 559-562 (1973).

16 Bas, B.: Staphylocoagulase; Academisch Proefschrift, Leiden (1973).

17 Hemker, H.C.; Dam-Mieras, M.C.E. van; Devilee, P.P.: The action of Echis carinatus venom on the blood coagulation system. Demonstration of an activator of factor X. Thromb. Res. 35: 1-9 (1984).

18 Stenflo, J.: Structural comparison of normal and dicoumarol-induced prothrombin; in Hemker, Veltkamp, Prothrombin and related coagulation factors, pp. 152-158 (Leiden University Press, Leiden 1975).

19 Stenflo, J.: Vitamin K and the biosynthesis of prothrombin. II. Structural comparison of normal and dicoumarol-induced bovine prothrombin. J. biol. Chem. 247: 8167-8175 (1972).

20 De Metz, M.; Soute, B.A.M.; Hemker, H.C.; Fokkens, R.; Lugtenburg, J.; Vermeer, C.: Studies on the mechanism of the vitamin $\mathrm{K}$-dependent carboxylation reaction; carboxylation without the concurrent formation of vitamin $\mathrm{K}$ 2,3-epoxide. J. biol. Chem. 257: 5326-5329 (1982).

21 Fasco, M.J.; Principe, L.M.: Vitamin $\mathrm{K}_{1}$ hydroquinone formation catalyzed by a microsomal reductase system. Biochem. biophys. Res. Commun. 97: 1487-1492 (1980).
22 Wallin, R.; Gebhardt, O.; Prydz, H.: NAD(P)H dehydrogenase and its role in the vitamin $\mathrm{K}$ (2methyl-3-phytyl-1,4-naphthaquinone)-dependent carboxylation reaction. Biochem. J. 169: 95-101 (1978).

23 Fasco, M.J.; Principe, L.M.: R- and S-warfarin inhibition of vitamin $\mathrm{K}$ and vitamin $\mathrm{K}$ 2,3-epoxide reductase activity in the rat. J. biol. Chem. 257: 4894-4901 (1982).

24 Wallin, R.; Hutson, S.: Vitamin K-dependent carboxylation. Evidence that at least two microsomal dehydrogenases reduce vitamin $\mathrm{K}_{1}$ to support carboxylation. J. biol. Chem. 257: 1583-1586 (1982).

25 Loeliger, A.E.; Esch, B. van der; Mattern, M.J.; Brabander, A.S.A. den: Behaviour of factors II, VII, IX and X during long-term treatment with coumarine. Thromb. Diath. haemorrh. 9: 74-89 (1963).

26 Thijssen, H.H.W.; Hemker, H.C.: Orale antistollingsbehandeling; welke anticoagulans? Ned. Tijdschr. Geneesk. 128: 1559-1563 (1984).

H.C. Hemker,

Departments of Biochemistry and Cardiology, Rijksuniversiteit Limburg, NL-6200 MD Maastricht (The Netherlands) 